\title{
DIE VERPLEECKUNDIGE AS SKEPPER VAN DIE TERAPEUTIESE OMGEWING
}

Oorgedruk uit GENEESKUNDE, Maart 1979, welwillend afgestaan deur die Redakteur

deur

\author{
S. P. Human, \\ B.Cur., Dip. V.o. Pret. \\ M. M. Faure,
}

B.A. (S.A.)., Dip. V.O. Pret.

D ie verpleegberoep stel hom ten doel om diens aan die gemeenskap op al die vlakke van gesondheidsdienste te lewer, d.i. op voorkomende, bevorderende, kuratiewe en rehabiliterende vlak. Die rol van die verpleegkundige in haar dienslewering aan die mens wat siek is, word gekenmerk deur instrumentele en ekspressiewe dimensies:

- die instrumentele as die konkrete, fisieke benadering tot die pasiënt

- die ekspressiewe wat temperend daarop inwerk deur die ondersteunings-, begeleidings- en vormingsfase van haar dienslewering aan en benadering tot die gemeenskap en die individu.

Dit stel die verpleegkundige in staat om 'n werklik betekenisvolle verhouding tussen haar en die pasiènt teweeg te bring, om in die woorde van Charlotte Searle, bo 'n pasiëntverpleegstersverhouding uit te styg tot 'n mens-tot-mensverhouding.'

Die verwerkliking van die ekspressiewe doelstellings van verpleging lê in die daarstelling van 'n omgewing waarin behandeling vir die pasiënt sinvol is en waarin dit vir hom moontlik word om alle aspekte van sy siekwese te bowe te kom. Skrywers verwys na hierdie omgewing as 'n terapeutiese omgewing.

\section{DEFINISIE}

'n Terapeutiese omgewing is die omgewing wat daargestel word sodat daar so min as moontlik spanning teenwoordig is en die pasiënt die geleentheid gebied word om weer sy optimale funksioneringsvlak te bereik.

\section{KENMERKE VAN 'N TERAPEUTIESE OMGE- WING EN DAARSTELLING DAARVAN DEUR DIE VERPLEEGKUNDIGE}

\section{Bekendheid met die Omgewing}

Die pasiënt moet bekend wees met sy omgewing. Praktiese wenke om die pasiënt tuis en op sy gemak te laat voel en waarvan die waarde nie onderskat moet word nie is o.a. om die pasiënt by opname vriendelik te verwelkom, hom te vergesel na sy bed, voor te stel aan medepasiënte, te wys waar die badkamer is, hoe die bedklokkie en die interkomstelsel gebruik kan word en aan hom te verduidelik wat die saalroetine min of meer is. Wanneer 'n pasiënt weet wat hy 'mag' en 'nie mag nie', wanneer wat in die afdeling plaasvind en wat presies van hom as pasiënt verwag word, is die omgewing waarin hy hom bevind in so 'n mate gestruktureerd dat hy bereid sal wees om daarby aan te pas en aktief deel te neem aan sy verpleegplan.

Reeds hier, met die eerste ontmoeting, word daar 'n verhouding tussen verpleegpersoneel en pasiënt opgebou wat kan bydra tot, of afbreuk kan doen aan, die daarstelling van 'n terapeutiese omgewing.

\section{Die Afwesigheid van Bedreiginge}

Wat die afwesigheid betref van enigiets wat die pasiënt as ' $n$ bedreiging kan ervaar, is veral die volgende belangrik:

(a) Die verpleegkundige is by uitstek die een wat beskikbaar is om te luister na die pasiënt i.s. dinge wat hy as dreigement aanvoel - hetsy probleme tuis, vrees vir 'n ondersoek of operasie, finansiële probleme of iets anders.

Daar is talle oomblikke van kontak met die pasiënt wat benut kan word vir gesprek en vir vasstel of daar wanindrukke en onsekerhede by die pasiënt bestaan; bv. terwyl sy die pasiënt bad, sy drukplekke versorg en sy medisyne toedien is daar geleentheid om te kommunikeer, gedagtes en gevoelens te bespreek en die pasiënt te help om perspektief te vind.

(b) Dit gebeur dikwels dat daar in sulke ingewikkelde terminologie met die pasiënt gekommunikeer word oor sy siektetoestand, 'n ondersoek wat gedoen moet word of chirurgie wat beplan word, dat die pasiënt dit glad nie verstaan nie. Die verpleegkundige kan deur inligting, raadgewing en verduideliking hierdie onbekende in so 'n mate vereenvoudig dat dit vir die pasiënt aanvaarbaar en sinvol word.

(c) Werklike gerusstelling verg meer as 'n paar troos woorde. Die volgende is nodig om ware gerusstelling te bereik:

Herkenning en erkenning van die pasiènt se behoeftes, angste of bekommernis; geleentheid aan die pasiënt om uiting te gee aan sy gevoelens; identifisering van die werklike probleem en die distansiëring daarvan deur die pasiënt; die pasiënt moet só in staat gestel word 
om self tot 'n oplossing te kom.

(d) Die volgende aspekte van die verpleegkundige se rol soos W. J. Kotzé dit sien, is hier van

belang:

- Die verpleegkundige gee sin aan die omgew-

ing waarin die pasiënt hom bevind.

"Singewing en aanvaarding is sinoniem aanvaarding nie as loutere berusting nie, maar as dinamiese en aktiewe verwerking van die mens se geworpenheid, tot sinryke en sinsverrykende bestaan. As die sieke nie tot aanvaarding en singewing kom nie, kan hy sy loekoms nie op hom neem nie.'?

- Die verpleegster is die skepper van 'n veilige ruimte en bewaarder van intimiteit in haar verhouding met die pasiënt. Op dié wyse word 'n omgewing van vertroue geskep waarin die mens in sy nood verstaan, gehelp en toegelaat word om sy waardigheid as mens te behou en te herwin indien nodig.

- Die verpleegster is immer "daar" as hulpverlener, steungewer en medeganger.

\section{Voorsiening in die Fisieke Behoeftes}

Wat betref die voorsiening in die fisieke behoeftes van die pasiënt en die skep van 'n terapeutiese omgewing, haal ek graag vir Virginia Henderson aan: "She (the nurse) must, in a sense, get inside the skin of each of the patients in order to know not only what he wants but also what he needs to maintain life and regain health. She is temporarily the consciousness of the unconscious, the move of life for the suicidal, the leg of the amputee, the eyes of the newly blind, a means of locomotion for the infant, knowledge and confidence for the young mother (and) a 'voice' for those too weak or withdrawn to speak." 3

'n wetenskaplik-gefundeerde verpleegprogram word na die mens se totale behoeftes omgesien.

Deur middel van opleiding, behoorlike inoefening, voortdurende opknapping van kennis en evaluering van haar vaardighede word die verpleegkundige in staat gestel om met selfvertroue te verpleeg. Dit op sigself is onvervangbaar in die skep van vertroue en 'n gevoel van veiligheid by die pasiënt.

\section{Beskerming van die persoon van die pasiënt}

Deur beperking van medies-geregtelike risiko's tot die minimum beskerming van die pasiënt se goeie naam, sy persoon en besittings word onveiligheid in die omgewing in 'n groot mate uitgeskakel.

\section{'n Skoon, Higiëniese Omgewing}

Die vyfde eienskap van 'n terapeutiese omgewing $\mathrm{nl}$. sindelikheid is van primêre belang vir die herstel van die pasiënt. 'n Skoon en higiëniese omgewing dra nie slegs by tot die voorkoming van infeksies nie, maar skep ook die gerusstelling by die pasiënt en sy familie dat die personeel werklik vir hom omgee. Baie nou hiermee saam hang ook die persoonlike netheid van die verpleegsters. Dit kan nie van die pasiënt verwag word om 'n persoon te vertrou wat ooglopend nie na haarself kan omsien nie. Die gereelde neem van deppers van die saal vir kweking van mikroörganismes, doeltreffende toesig oor die skoonmaak van die afdeling, noulettendheid omtrent die netheid van personeellede en behoorlike opleiding van alle personeellede i.s. steriliteit en sterilasietegnieke, dra nie slegs by tot die skep van 'n terapeutiese milieu nie, maar verhoog beslis die kwaliteit van sorg en aandag wat aan die pasiënt gelewer word.

\section{Aanvaarding van die Pasiënt as Individu}

Die laaste vereiste vir die skep van 'n terapeutiese omgewing is aanvaarding van die pasiënt as individu en as persoonlikheid in eie reg. In haar professionele optrede moet die verpleegkundige die pasiënt sien:

- as medemens, as, sóós sy, uniek en onvervangbaar;

- as menswaardig en in staat tot verantwoordelikheid;

- as 'n persoon met eie reg op besluitneming;

- as 'n persoon met moontlikheid - daarom durf hy nooit afgeskryf word as 'n "hopelose geval" nie;

- as intensionele wese en gesprekvoerder, selfs in onafwendbare krisistye soos die sterfbed.

Die verpleegkundige moet daarteen waak dat die pasiënt in afhanklikheid van die verpleegpersoneel verval. Hy moet aangemoedig word en in so ' $n$ mate by die verpleegplan betrek word dat hy as selfstandige en verantwoordelike persoon, ook m.b.t. sy eie gesondheid na die gemeenskap sal kan terugkeer.

\section{GEVOLGTREKKING}

'n Terapeutiese omgewing wat aan al die gemelde vereistes voldoen, word daargestel in 'n behoorlikfunksionerende hospitaal waar daar dissipline en 'n hoë standaard van pasiëntsorg gehandhaaf word, waar die personeel getrou, kundig en vaardig is en waar opleidingstandaarde hoog is.

Die hele hospitaalspan, vanaf die geneesheer tot die skoonmaker, dra by tot die skep van so 'n omgewing. Dit is egter die verpleegkundiges wat die grootste verantwoordelikheid dra, want dit is immers hulle wat 24 uur per dag na die pasiënt omsien. Dit is hulle wat alle dienste wat aan die pasiënt gelewer word, koördineer.

Dit is ook die verpleegkundige wat aanspraak daarop kan maak dat selfs al is die pasiënt besig om te sterf, sy nog altyd 'n taak het om te vervul wat veel meer betekenisvol is as versorging van sy kwynende fisieke vermoëns.

'n Verpleegkundige bereik nooit dié punt waar sy kan sê: "Ek kan nou niks meer vir jou doen nie." 